\title{
Analysis of Needs for the Development of Physical Education Learning Model in Elementary School Based on Traditional Game
}

I Ketut Yoda ${ }^{1, *}$ I.P. Adi Wibowo ${ }^{2}$ Ria Tri Harini Dwi Rusiawati ${ }^{3}$ Ketut Chandra

Adinata Kusuma ${ }^{4}$ Gede Doddy Tisna M.S ${ }^{1}$

\author{
${ }^{1}$ Sports Science Study Program, Universitas Pendidikan Ganesha, Singaraja, Indonesia \\ ${ }^{2}$ Medical Study Program, Universitas Pendidikan Ganesha, Singaraja, Indonesia \\ ${ }^{3}$ Midwifery Study Program, Universitas Pendidikan Ganesha, Singaraja, Indonesia \\ ${ }^{4}$ Sports Coaching Education Study Program, Universitas Pendidikan Ganesha, Singaraja, Indonesia \\ *Corresponding author.Email: yodaketut@undiksha.ac.id
}

\begin{abstract}
The aim of this research is to obtain information and data related to the analysis of the need for the development of physical education and health learning model based on traditional game in elementary schools. The population of this study were 50 elementary schools in Buleleng District consisting of 13 private elementary schools and 37 public elementary schools. Determination of the sample is determined randomly and selected proportionally in each elementary school. Each of these schools has heterogeneity, environment, and customs that are different, so these schools are also considered in determining the research sample. Data were collected using participatory observation methods, documentation studies, interviews, FGDs, and questionnaires (questionnaires. The results of the study are based on the competencies expected from the implementation of learning (standardized processes) of the elementary school Physical Education (PE) curriculum, student characteristics, and the opinions of elementary school PE teachers, so a learning model for SD PJOK based on traditional Balinese games is needed to improve students' physical fitness, manipulation Motor Skill and Character of Elementary School students.
\end{abstract}

Keywords: Learning models, Physical education, Traditional games.

\section{INTRODUCTION}

Physical Education (PE) is an educational process through the assistance of learning experiences for learners in form of physical activities, games, and sports that are consistently prepared to encourage improvement of physical, organic, motor skills, thinking skills, emotional, social and moral. The provision of learning experiences is directed at fostering, as well as forming a healthy and active lifestyle throughout life. $\mathrm{PE}$ is a method of purposefully and systematically educating a student as an individual or a member of society through numerous physical exercises to gain physical growth, health and physical fitness, abilities and skills, intelligence and character improvement, as well as having a pleasant personality. Harmony in the context of the development of Indonesian people based on Pancasila [1].
In the intensification of the realization of education as a procedure of human improvement that lasts a lifetime, the function of $\mathrm{PE}$ is essential, namely preparing opportunities for students to be directly involved in numerous learning practices through systematic physical activity, play, and sports activities. This is a tool to encourage the expansion of motor skills, physical abilities, knowledge and reasoning, appreciation of values (mental, emotional, spiritual and social attitudes), as well as habituation of healthy lifestyles that lead to encouraging equitable growth and development.

The burden of learning at school is so heavy and suppresses children's freedom to move. Their need for movement cannot be fulfilled because of limited time and opportunity. The school environment does not provide an interesting area to explore. Education providers in schools that prioritize academic 
achievement, give children learning tasks that accumulate. Such school life is also combined with life at home and outside the school environment. If at school the child is less mobile, at home the situation is the same. Technological advances achieved at this time, even confine children in a sedentary environment. Children are getting more and more engrossed in their pleasures such as watching television or playing video games. Not surprisingly, there are concerns that children's fitness is declining. With the lower physical fitness, the symptoms of hypokinetic disease (lack of movement) also increase. Obesity, high blood pressure, diabetes, lower back pain, are examples of sedentary diseases. As a result, heart disease is no longer a monopoly of adults, but has also attacked children. In line with that, knowledge and bad eating habits also exacerbate health problems that threaten people's welfare. With excessive nutrition patterns, the 'movement lazy' will accumulate fat in their bodies excessively. They expose themselves to a greater risk of degenerative diseases (decreased organ function).

PE appears to overcome these problems so that its position is considered important. Through well-planned programs, children are involved in high-intensity physical activities. PE also continues to provide space for learning to explore the surrounding environment by trying a lot, so that the activities remain in accordance with the interests of the child. The main goal of physical education is to guide children to be physically active to fill their spare time [2]. It is through physical education that children find the right channels to move freely and regain their joy, while being stimulated by holistic development.

Through PE learning, students will gain some experience, such as; positive personal, various creative, innovative expressions, movement skills, physical fitness, healthy lifestyles, human movement knowledge and understanding, and also develop a positive personality. Physical activity in the form of sports activities, exercises, physical education, and playing, makes a very important contribution to children's development, and children really enjoy throughout these activities [3]. In terms of PE goals to physical capacity development, the development process must be carried out from elementary school to university [4]. PE is a number of selected human physical activities carried out to achieve the intended outcomes. This understanding is backed up by the understanding that: 'When the mind (mental) and body are referred to as two separate elements, PE which emphasizes understanding the natural side of human nature when the individual whole is an undeniable fact, PE is defined as education through physical. This understanding shows that PE is also related to emotional responses, personal relationships, group behavior, mental, intellectual, emotional, and aesthetic learning [5].
Another opinion but in a similar expression, as expressed by Barrow (2001) is that physical education can be defined as education about and through human movement, when educational goals are achieved through the media of muscle activity, including: sport (sport), games, gymnastics, and physical exercise (exercise). The results to be achieved are physically educated individuals. This value becomes one of the values of an educated individual, and is meaningful when it only relates to the side of the individual's life [5].

In placing the position of $\mathrm{PE}$, it is also believed that the contribution of PE will only be meaningful when the experiences of motion (physical activity) in PE are related to the process of one's life as a whole in society. Thus, when experience in PE does not contribute to other educational experiences, then there must be errors in the implementation of the PE program. PE is a physical activity that requires serious effort. Furthermore, these two experts stated that: 'PE is a process of adaptation and learning organically, neuromuscularly, intellectually, socially, culturally, emotionally, and aesthetically resulting from the process of selecting various physical activities.

The selected physical activity is adjusted to the goals to be achieved and the student's capabilities. The selected physical activity emphasizes a variety of reasonable physical activities, physical activities that require little effort as recreational activities and or physical activities that require great effort such as for sports activities, coaching or achievement.

PE focuses on all forms of physical activity that activates large muscles (gross motor), focuses on physical movement in games, sports, and basic functions of the human body. Thus, states that physical education can be categorized into three groups [5], namely: 1) PE is carried out through physical media, namely: several physical activities or several types of body movements; 2) Physical activity although not always, but generally includes a variety of gross motor activities and skills that do not always have a striking difference; 3) Although students benefit from this physical activity process, the benefits for students do not always have to be physical, non-physical can also be achieved such as: intellectual, social, and aesthetic development, as well as cognitive and affective development.

Overall, the understanding that must be captured is: physical education uses physical media to develop the total welfare of everyone. The characteristics of PE like this are not found in other subjects, because the educational outcomes of physical learning experiences are not limited to body development. The context through physical activity in question is a complete context concerning all dimensions of human beings, such as the relationship between body and mind. Of 
course, PE not only causes a person to be physically educated, but also all aspects related to total human well-being, as is meant by the concept of "lifelong physical fitness". As is known, the dimensions of the relationship between body and mind emphasize three educational domains, namely: psychomotor, affective, and cognitive. PE emphasizes aspects of comprehensive education (health, physical fitness, critical thinking skills, emotional stability, social skills, reasoning and moral action), which is the general objective of education. Else, especially through physical education learning, Students engage in activities that take the form of games (games), and exercise (adjusted to the growth and improvement of children). There is no education that does not have a pedagogical goal, and education is not complete without physical education, because movement is the basis for humans to know the world and themselves which naturally develops in the direction of the times. The role of PE in schools is very important for the development of body organs in improving physical health and fitness, neuromuscular development, mental-emotional development, social development, and intellectual development. The body is the main foundation in building a healthy generation, physically, mentally, socially and spiritually. Thus, in learning PE the most important thing is how a PE teacher is able to bring every child to be able to grow and develop both physically, psychomotor, affective, cognitive, and spiritual to the maximum according to the potential possessed by the child.

In order to comprehend the meaning of PE, one must also important to think about the connection between sport and play, as terms that were popular earlier and are more often used in the context of daily activities. This understanding will help teachers or the community in understanding the role and function of physical education more conceptually. Play, sport, and PE involve various forms of movement, and all three can fit well in an educational context if used for educational purposes. Sport and play can exist for pleasure, education, or a combination of the two. Fun and education can and should go hand in hand.

The implementation of PE in schools must be designed and accommodate local culture. Because children will always learn in a comfortable and fun way when children feel the learning is carried out in accordance with the experiences previously obtained in their family which has become a culture in the family. One of the local cultures that is currently being eroded in Balinese society as a result of the onslaught of technology is the Balinese traditional game.

Traditional games are one of the local Balinese cultures that can be used as one of the contents in PJOK learning, especially in Elementary Schools, which is in accordance with the characteristics of elementary students. Based on the results of research $100 \%$ of the
PE teachers included traditional games in elementary school education lessons, but they were only played for about ten to fifteen minutes when giving a warm-up or introductory lesson [6]. This condition certainly must receive an in-depth study so that traditional games are not only used as a warm-up activity but also included as a core activity of PE learning with a longer duration of time. Playing is one way to help children develop their potential at a young age. One prayer game that can be used in playing early childhood is traditional games, because traditional games contain many elements of benefits and preparation for children to live social life [7]. Traditional games can encourage children to improve cooperation, hand children to adjust, connect positively with each other, help children in self-control, develop empathy for friends, obey rules, and respect others [8]. Then, traditional games can be seen as having a positive impact on the development of children's emotional and social skills. This traditional character value can also develop in children, such as religious values, nationalism, independence, mutual cooperation, integrity [7][9]. Traditional games have a function in developing children's basic abilities, they are easy to do both in how to play and make game tools [9].

\section{METHOD}

This research is a development research with a modified development research design of Gall and Gall 2003 [10]. The goal of this study is to investigate the needs of the importance of developing PJOK learning in elementary schools based on Balinese Traditional Games. The research location is in Buleleng District, which has 50 elementary schools, consisting of 13 private elementary schools and 37 public elementary schools. Determination of the sample is determined randomly and selected proportionally in each elementary school. Each of these schools has heterogeneity, environment, and customs that are different, so these schools are also considered in determining the research sample.

Data were collected using participatory observation methods, documentation studies, interviews, FGDs, and questionnaires (questionnaires). The data of this research are qualitative and quantitative data, then the data processing uses descriptive qualitative methods. In accordance with the qualitative descriptive data analysis method, the procedure of data analysis carried out were: (1) after data collection completed, the authors conducted data reduction by summarizing the field reports, noting the main points relevant to the research focus, (2) systematically compiling based on certain categories and classifications, (3) present data in form of tables or pictures so that the relationship between one data and another becomes clear and intact (4) conducts cross site analysis by comparing and analyzing data individually. in-depth, and (5) presenting findings, 
making conclusions in the form of general trends and implications for their application, and recommendations for development.

\section{RESULTS AND DISCUSSION}

Based on the Regulation of the Minister of Education and Culture of the Republic of Indonesia Number 67 of 2013 concerning the Basic Framework and Curriculum Structure of Elementary Schools/Madrasah Ibtidaiyah that there are 4 aspects of competence to be achieved in PE subjects namely; 1) Accept and practice the teachings of their religion (spiritual aspect); 2) Demonstrate honest, disciplined, responsible, polite, caring, and confident behavior in interacting with family, friends, teachers and their household (attitude aspect); 3) Understanding factual knowledge by observing (hearing, seeing, reading) and asking questions based on curiosity about himself, God's creatures and their activities, and objects they encounter at home and at school (knowledge aspect); and 4) Presenting factual knowledge in clear, systematic and logical language, in aesthetic works, in movements that reflect healthy children, and in actions that reflect the behavior of children with faith and noble character (skill aspect) [11].

To achieve these four aspects of competence as a PE teacher is not an easy thing. Some things that are needed in achieving competence for elementary school children specifically in learning PE are: 1) Professional PE teachers. According to the Law of the Republic of Indonesia concerning Teachers and Lecturers, Article 8 states that: Teachers are expected to have certain qualifications, they are; academic qualifications, competencies, educator certificates, physically and mentally healthy, and having the ability to fulfil national educational objectives. Teacher competencies as referred to in Article 8 include pedagogic competencies, personality competencies, social competencies, and professional competencies obtained through professional education. 2) Learning models and scenarios that are in accordance with the characteristics of students [12]. As many as $87.6 \%$ of primary school primary school teachers use cooperative learning models, the rest (12.4\%) use lecture, demonstration, and reciprocal methods [6]. A learning model is a blueprint or pattern that is used to design classroom learning and determine learning aids such as books, computers, curricula, and other resources. [13]. An instructional model refers to a extensive and systematic design for teaching that includes a theoretical basis, expected learning outcomes, teacher's subject knowledge expertise, steps of learning activities, requirement of teacher and student behaviours, unique task, evaluation of learning outcomes, and mechanisms for assessing the implementation of the model [14].
The learning model is a conceptual framework that defines a systematic approach for organizing learning experiences in order to attain specific objectives and serves as a guide for educators. guide in planning and implementing learning. In creating teaching and learning activities, the learning model also serves as a guide for learning designers and teachers. The learning model is based on a learning view that includes learning theory, learning objectives, learning context and content, classroom management, teaching strategies, processes and student learning assessments. The learning model refers to the approach to be used, including learning objectives, stages in learning activities, learning environment, and classroom management. Through the learning model, teachers can help students get information, ideas, skills, ways of thinking, and expressing ideas [15]. Characteristics of elementary school-aged children are happy to play, love to move, love to work in groups, and enjoy feeling/doing things directly. Therefore, teachers should develop learning that contains elements of the game, allows students to move or move and work or study in groups, and provide opportunities for students to be directly involved in learning. To fulfill quality and meaningful PE learning, one of the teacher's efforts is learning that mixes learning models by including local wisdom content such as traditional Balinese games in the learning scenario.

Based on the research results, $100 \%$ of the teachers stated that they included the content of local wisdom (traditional Balinese games) explicitly in the learning scenario. As many as $65.2 \%$ apply traditional games when learning takes place for 5-10 minutes, $30.4 \%$ for 15-20 minutes, and 8.7\% more than 20 minutes. The response of students delivered by PE elementary school teachers to the application of traditional games during learning was very good where $100 \%$ of the students looked very happy and did well and there were also students who did not want to stop and wanted to continue playing. $95.7 \% \%$ of the teachers stated that traditional Balinese games are very suitable to the characteristics of elementary school students and can also be used as one of the PE learning materials in improving Physical Fitness, Manipulative Movement Skills and Student Character [6].

States that children's physical development does not solely depend on the maturity process. This development is also influenced by the child's movement experience, both in terms of quality and the number of experiences. Learning PE Elementary School Based on Culture will greatly facilitate students in providing adequate motion experience for the development of physical fitness, manipulative motor skills, and student character. Traditional games allow children to move in situations full of joy, happiness, togetherness, help each other, compete with each other with full responsibility so that gross motor skills will be trained well without 
realizing it [16]. With traditional games all students who play move either in place or perform non-locomotor and locomotor movements (for example in avoiding opponent attacks), move while using tools or often called manipulative movements when they have to attack opponents using a ball, as well as fast running movements. orlocomotor movements provide double benefits for children in increasing gross motor skills and fundamental motor skills. Another benefit of traditional games is that it has been tested in this research, which is being able to develop the character of PAUD students [17][18].

Various advantages that can be obtained from the application of traditional games. Traditional games in elementary school learning are in accordance with the level of movement development and physical activity required by elementary school children, namely activities that contain many elements of play. Play activities are physical activities carried out by all age levels and must be carried out by elementary school children as a marker that the child is in normal growth. Playing for elementary school-age children is one of the activities used by children in their development to get to know the surrounding environment, which is carried out with joy, without any burden but provides benefits in the totality of children's development, namely, physically, mentally, and spiritually.

The results of this study indicate that, in general, elementary schools in Buleleng District already have adequate facilities and infrastructure for the implementation of PE learning. Resource and framework in a school is quite influential on the quality of the school. Therefore, the government through the Ministry of Education and Culture has made standards for facilities and infrastructure for each type and level of education. With the standard facilities and infrastructure, teaching and learning activities in the school environment can run smoothly and conductively while still prioritizing the safety of students. Each education system is required to have resource, including land, classrooms, unit leadership room, teachers' room, administration room, library, laboratory, workshop, production unit room, canteen, power and service installation, exercise area, places for worship, playground, places to be creative, and other spaces/places needed to support sustainable learning process [19].

\section{CONCLUSION}

Based on the results of the needs analysis, in terms of the competencies expected from the implementation of learning (standardized process) of the Elementary School PE curriculum, student characteristics, and the opinions of Elementary School PE teachers, a learning model for PE in Elementary School based on local wisdom (traditional Balinese games) is urgently needed, in improving the Physical Fitness, Manipulation of Motor Skills and Characters of Elementary School students. In addition, based on the conclusions above, it is for PE teachers that learning scenarios are designed based on Balinese traditional games.

\section{ACKNOWLEDGMENTS}

Thank you to the Rector of the Ganesha University Education for the opportunity and funding provided to researchers, thank you to Elementary School Physical Education Teachers and Head Master in Buleleng subdistrict for their cooperation in providing information to obtain research data, and finally thank you to the research team for their cooperation in do this research

\section{REFERENCES}

[1] T. C. Mutohir, Gagasan-Gagasan Tentang Pendidikan Jasmani dan Olahraga. Surabaya: Unesa University Press, 2002.

[2] C. Himberg, G. Hutchinson, and J. M. Roussell, Teaching Secondary Physical Education: Preparing Adolescents to Be Active for Life, 1st editio. United States: Human Kinetics, 2002.

[3] K. T. Thomas, A. M. Lee, and J. R. Thomas, Physical Education Methods for Elementary Teachers, Third Edit. United States: Human Kinetics, 2008.

[4] W. D. Dwiyogo, Olahraga dan Pembangunan. Malang: Wineka Media, 2009.

[5] W. H. Freeman, Physical Education and Sport in a Changing Society, 5th editio. Boston: Allyn \& Bacon, 2001.

[6] I. K. Yoda, I. P. A. Wibowo, and T. H. D. R. Ria, "Pengembangan Model Pembelajaran Pendidikan Jasmani dan Olahraga (PJOK) Berbasis Kearifan Lokal Di Sekolah Dasar Untuk Meningkatkan Kebugaran Jasmani, Manipulatif Motor Skill, Dan Karakter," Singaraja, 2021.

[7] T. Andriani, "Permainan Tradisional Dalam Membentuk Karakter Anak Usia Dini," J. Sos. Budaya, vol. 9, no. 1, pp. 121-136, 2012, doi:

http://dx.doi.org/10.24014/sb.v9i1.376.

[8] E. Kurniati, "Program Bimbingan Untuk Mengembangkan Keterampilan Sosial Anak Melalui Permainan Tradisional," Universitas Muhammadiyah, 2011.

[9] N. E. Saputra and Y. N. Ekawati, "Permainan Tradisional Sebagai Upaya Meningkatkan Kemampuan Dasar Anak Tradisional Games in Improving Children'S Basic Abilities," J. Psikol. 
Jambi, vol. 2, no. 2, pp. 48-53, 2017, doi: https://doi.org/10.22437/jpj.v2i2.4796.

[10] M. D. Gall, J. P. Gall, and W. R. Borg, Educational Research: An Introduction, 7th editio. United States: Allyn and Bacon, 2003.

[11] M. Nuh, Peraturan Menteri Pendidikan dan Kebudayaan Tentang Kerangka Dasar Dan Struktur Kurikulum Sekolah Dasar/Madrasah Ibtidaiyah. Republik Indonesia, 2013.

[12] Dewan Perwakilan Rakyat Indonesia, UndangUndang tentang guru dan dosen. Republik Indonesia, 2005.

[13] Trianto and Sunarni, Model-model Pembelajaran Inovatif Berorientasi Konstruktivistik: Konsep, Landasan Teoritis-Praktis dan Implementasinya, Cetakan 5. Jakarta: Prestasi Pustaka, 2011.

[14] M. W. Metzler, Instructional Models for Physical Education, 3rd Editio. United States: Holcomb Hathaway, 2005.

[15] A. Suprijono, Cooperative Learning Teori dan Aplikasi PAIKEM. Yogyakarta: Pustaka Belajar, 2013.

[16] R. Lutan, Ilmu Keolahragaan dan Beberapa Isu Filosofis - Manusia dan Olahraga. Bandung: ITB, 1996.

[17] I. K. Yoda, M. A. Wijaya, and N. P. D. S. Wahyuni, "Pengembangan Model Motor LearningBerbasis Budaya untuk Meningkatkan Fundamental Skill, Gross Motor Skill dan Karakter Pada Siswa PAUD di Kabupaten Buleleng," Singaraja, 2018.

[18] I. K. Yoda and G. D. Tisna, "Evektivitas Pendidikan Jasmani Di Sekolah Dasar Ditinjau Dari Kebugaran Jasmani Dan Obesitas Siswa Sekolah Dasar," Singaraja, 2020.

[19] B. Sudibyo, Peraturan Menteri Pendidikan Nasional Tentang Standar Sarana dan Prasarana Untuk Sekolah Dasar/Madrasah Ibtidaiyah (SD/MI), Sekolah Menengah Pertama/Madrasah Tsanawiyah (SMP/MTs), Dan Sekolah Menengah Atas/Madrasah Aliyah (SMA/MA). Republik Indonesia, 2007. 